\title{
The 1996 and 1997 National Survey of Physician Asthma Management Practices: Background and study methodology
}

\author{
Robert L Jin MD MHSc CCFP FRCPC, Bernard CK Choi PhD MSc \\ Respiratory Disease Division, Bureau of Cardio-Respiratory Diseases and Diabetes, \\ Laboratory Centre for Disease Control, Ottawa, Ontario
}

\begin{abstract}
RL Jin, BCK Choi. The 1996-97 National survey of physician asthma management practices: Background and study methodology. Can Respir J 1999;6(3):269-272.
\end{abstract}

OBJECTIVES: To collect national baseline information on asthma management practices by physicians, and to compare these practices with the recommendations of the Canadian Asthma Consensus Conference ('the guidelines').

DESIGN: Cross-sectional survey of representative samples of physicians in Canada in late 1996 and early 1997.

POPULATION STUDIED: Five specialty types of physicians who manage asthma patients: respirology, pediatrics, internal medicine, allergy and clinical immunology, and general practice and family medicine. Stratified sampling by province and specialty was used to select physicians for the study. Weighting was used in the analysis to generalize the results to the national level for the five specialty groups of physicians.

METHOD: Mailed questionnaire, self-administered by the respondent; three mailings of the questionnaires were used to increase the response rate.

MAIN RESULTS: The frequency with which each of the five specialty types chose specific asthma management choices was determined, using weighted percentages representative of the specialty groups on a national basis. ANOVA determined the statistically significant differences among the five specialties in choosing particular asthma management actions. Then, logistic regression was used to calculate the odds ratios showing an association between the characteristics of the physician respondents and specific asthma management choices that they made in the survey.

CONCLUSIONS: The data analysis demonstrated significant variations among physicians in asthma management practices, according to specialty type and other characteristics. The initial report was released in April 1998, and manuscripts for journal submissions are being prepared.

Key Words: Asthma management; Consensus guidelines; Physicians; Practice variations

Enquête nationale de 1996 et 1997 sur les pratiques de prise en charge de l'asthme par les médecins : historique et méthodologie de l'étude

OBJECTIFS : Recueillir de l'information de base au niveau national sur les pratiques de prise en charge de l'asthme par les médecins, et comparer ces pratiques avec les recommandations de la Conférence canadienne de consensus sur l'asthme (Lignes directrices).

voir page suivante

Correspondence: Dr Robert Jin, clo Global Surveillance and Field Epidemiology, LCDC, Tunney's Pasture AL \#0900B, Ottawa, Ontario K1A 0K9. Telephone 613-954-3236, fax 613-952-8286, e-mail robert_jin@hc-sc.gc.ca 
MODÈLE : Enquête transversale auprès d'échantillons représentatifs de médecins canadiens, menée de la fin de l'année 1996 au début de l'année 1997.

POPULATION ÉTUDIÉE : Cinq spécialités types de médecins qui traitent des asthmatiques, soit la pneumologie, la pédiatrie, la médecine interne, l'allergologie et l'immunologie clinique ainsi que la médecine générale et la médecine familiale. Un échantillonnage stratifié par province et par spécialité a été utilisé pour la sélection des médecins retenus pour l'étude. La pondération a été utilisée dans l'analyse pour généraliser les résultats au niveau national pour les cinq groupes de médecins-spécialistes.

MÉTHODES : Questionnaire postal, rempli par le répondant même ; les questionnaires ont été envoyés à trois reprises par la poste pour augmenter le taux de réponse.

PRINCIPAUX RESULTATS : La fréquence à laquelle chacune des cinq spécialités a mentionné des choix de traitement spécifiques pour l'asthme a été déterminée à l'aide de pourcentages pondérés représentatifs des groupes de spécialité à l'échelle nationale. Une analyse de variance a déterminé les différences statistiquement significatives parmi les cinq spécialités dans le choix de certaines pratiques de traitement de l'asthme. Ensuite, on a procédé à une régression logistique pour calculer le risque relatif démontrant une association entre les caractéristiques des répondants médecins et les choix de traitement spécifiques pour l'asthme mentionnés dans le questionnaire.

CONCLUSIONS : L'analyse de ces données a démontré des variations significatives parmi les médecins quant aux pratiques de traitement de l'asthme, selon le type de spécialité et d'autres caractéristiques. Un premier rapport a paru en avril 1998, et on prépare actuellement les abrégés destinés à la publication.
$\mathrm{T}^{\mathrm{s}}$ he Laboratory Centre for Disease Control (LCDC) of Health Canada regards the implementation of the recommendations ('guidelines') from the 1998 Canadian Asthma Consensus Conference to be of vital importance for the effective control of asthma in Canada. As Canada's national public health agency for disease surveillance, prevention and control, LCDC identified the trends of increasing mortality and hospitalization rates due to asthma during the 1970s and 1980s. Asthma remains a prevalent condition. The National Population Health Survey (1996-97) reported that $6 \%$ of the population two years of age and over fit the definition of having 'current asthma', nearly two million people in Canada (unpublished data, Statistics Canada).

In late 1994, following the LCDC's identification of the control of asthma as a public health priority, it formed the National Asthma Control Task Force, comprising 15 national health professional, patient and consumer organizations concerned with asthma in Canada. LCDC, specifically the Respiratory Disease Division, Bureau of CardioRespiratory Diseases and Diabetes, has served as the secretariat and funder of the Task Force, which is accountable to the Director General of the LCDC.

As its mandate, the Task Force has developed a National Asthma Control Strategy with the overall goal of reducing asthma mortality and morbidity in Canada. The strategy has 12 stated objectives with measurable 'targets'; specific objectives include achieving the "correct diagnosis of asthma" and the "appropriate management of asthma by physicians". The clinical practice guidelines, developed by the Canadian Asthma Consensus Conference in 1995 (1), and updated in 1998 and 1999, thus, comprise an essential means of realizing the key objectives of the National Asthma Control Strategy.

In 1996, the LCDC commissioned a national survey of how physicians manage asthma in their patients ('manage' comprising the clinical activities of diagnosis, treatment, education and follow-up of patients). The main objectives of the survey were to establish national baseline information on asthma management practices; to describe the variations in these practices according to the physicians' specialty type and other characteristics, and to compare the survey results with the practices as recommended by the 1995 Consensus Conference.

\section{STUDY METHOD}

The questionnaire for this study - called the Physician Asthma Management Survey - was designed by the LCDC (Respiratory Disease Division), in collaboration with a steering committee representing the following specialties: respirology, family medicine, emergency medicine, pediatrics, allergy and clinical immunology, nursing and epidemiology, and professional medical education. (See the Acknowledgements at the end of this article for the names of the steering committee members and the LCDC co-investigators.) Five specialties of physicians who manage asthma patients were surveyed: respirology, pediatrics, internal medicine, allergy and clinical immunology, and general practice and family medicine. Emergency room physicians had previously conducted and published their own national survey (2).

Data collection: The questionnaire described three clinical scenarios: a 17-year-old female patient with a mild to moderate exacerbation of asthma, an 18-year-old male with a more severe exacerbation, and a four-year-old female with symptoms suggestive of asthma but not yet diagnosed. For these scenarios, physicians were asked about their diagnostic and treatment decisions. They were also asked direct questions about the use of various methods for diagnosing, treating, educating and following-up patients with asthma.

The questionnaires were mailed to 4489 physicians in the five specialty types in all 10 provinces and two territories during late 1996 and early 1997. The sample size of each category of physicians was chosen such that the study could detect, for a particular outcome, a difference of $10 \%$ in prevalence among the categories with a $95 \% \mathrm{CI}$, assuming an overall response rate of $60 \%$.

In anticipation of a potentially low level of response by physicians to a mailed, self-administered survey, a number of steps were taken to maximize the response rate. Included with the questionnaire was a bilingual cover letter from Health Canada that included the signatures of the steering 
TABLE 1

Independent variables used in logistic regression modelling of associations between physician characteristics and asthma management choices made in the National Survey of Physician Asthma Management Practices

\begin{tabular}{|c|c|}
\hline $\begin{array}{l}\text { Independent variables } \\
\text { used by both Price } \\
\text { Waterhouse and LCDC }\end{array}$ & $\begin{array}{l}\text { Physician } \\
\text { respondent } \\
\text { characteristics }\end{array}$ \\
\hline Sex & Male or Female \\
\hline Age group & $\begin{array}{l}\text { Less than } 35 \text { years, } 35 \text { to } 64 \text { years, } \\
\text { over } 65 \text { years }\end{array}$ \\
\hline Specialty type & $\begin{array}{l}\text { Family physician or general } \\
\text { practioner, pediatrics, allergy, } \\
\text { respirology, internal medicine }\end{array}$ \\
\hline $\begin{array}{l}\text { Region of Canada } \\
\text { (location of practice) }\end{array}$ & $\begin{array}{l}\text { Atlantic provinces, Quebec, Ontario, } \\
\text { Prairies or Territories, British } \\
\text { Columbia }\end{array}$ \\
\hline Rural status & $\begin{array}{l}\text { Yes or no (practicing in community } \\
\text { less than } 10,000 \text { people) }\end{array}$ \\
\hline $\begin{array}{l}\text { Number of years in } \\
\text { practice }\end{array}$ & Years (as self-reported) \\
\hline $\begin{array}{l}\text { Average number of asthma } \\
\text { patients seen per month }\end{array}$ & Average number (as self-reported) \\
\hline $\begin{array}{l}\text { "Knowledgeable" about } \\
\text { Consensus guidelines }\end{array}$ & Yes or no (as self-reported) \\
\hline $\begin{array}{l}\text { Membership in national } \\
\text { medical organizations }\end{array}$ & $\begin{array}{l}\text { Canadian Medical Association, } \\
\text { College of Family Physicians of } \\
\text { Canada and/or Royal College of } \\
\text { Physicians and Surgeons of Canada }\end{array}$ \\
\hline
\end{tabular}

LCDC Laboratory Centre for Disease Control, Ottawa, Ontario; Price Waterhouse Consultants, Toronto, Ontartio

committee members and their respective national medical organizations. Two weeks after the first mailing, a reminder card was sent; three weeks after that, the questionnaires were mailed a second time.

After the second mailing, the response rate was $35 \%$. To improve the response rate further, a shortened version of the original questionnaire was developed in consultation with the steering committee. Pretesting of the abbreviated questionnaire showed that it could be completed by physicians in 5 mins. The third mailing of the survey consisted of both the short form questionnaires and the original (long form) questionnaires being sent to separate groups of physicians who had not replied to the first two mailings. Personalized cover letters (addressed to the recipients) were included with the questionnaires. The final overall response rate was $52 \%$.

Data analysis: Price Waterhouse Consultants (Toronto, Ontario) were contracted by LCDC to mail the questionnaires, to collect the responses, and to conduct initial data analysis and interpretation. LCDC subsequently conducted further analysis of the survey data.

Two types of data analysis were completed. The first was a descriptive analysis that described the weighted percentages of each of the five specialty types who chose various responses on the survey, ie, the various 'asthma management choices'. The percentages were weighted according to the

\section{TABLE 2}

Dependent (outcome) variables used in logistic regression modelling of associations between physician characteristics and asthma management choices made in the National Survey of Physician Asthma Management Practices

\begin{tabular}{|c|c|}
\hline $\begin{array}{l}\text { Outcome variables used } \\
\text { by both Price Waterhouse and } \\
\text { Laboratory Centre for } \\
\text { Disease Control }\end{array}$ & $\begin{array}{l}\text { Additional outcome } \\
\text { variables used by } \\
\text { Laboratory Centre for } \\
\text { Disease Control }\end{array}$ \\
\hline $\begin{array}{l}\text { Using spirometry "almost } \\
\text { always" or "often" for } \\
\text { diagnosing adults and children } \\
\text { over age six years }\end{array}$ & $\begin{array}{l}\text { Ordering peak expiratory flow } \\
\text { rates (PEFR) "almost always" } \\
\text { or "often" for diagnosis, } \\
\text { Increasing the dose of inhaled } \\
\text { short-acting beta2-agonist in } \\
\text { scenario } 1\end{array}$ \\
\hline $\begin{array}{l}\text { Using spirometry "almost } \\
\text { always" or "often" for the } \\
\text { follow-up of patients }\end{array}$ & $\begin{array}{l}\text { Ordering PEFR at home "almost } \\
\text { always" or "often" for follow-up } \\
\text { of patients }\end{array}$ \\
\hline $\begin{array}{l}\text { Using spirometry for an older } \\
\text { adolescent with a mild to }\end{array}$ & $\begin{array}{l}\text { Ordering spirometry in office/ lab } \\
\text { for scenario } 1\end{array}$ \\
\hline
\end{tabular}
moderate exacerbation of asthma ("scenario 1")

Ordering a chest $\mathrm{x}$-ray or complete blood count for scenario 1
Prescribing antibiotics for a young adult with a moderate to severe exacerbation of asthma ("scenario 2")
Prescribing xanthines for scenario 2

\section{Selecting a treatment in scenario 1 that was "not recommended by the guidelines"}

Choosing certain "active" methods of patient education "almost always" or "often"

"Knowledgeable" about the Canadian consensus guidelines*

Prescribing inhaled anticholinergics for scenario 2

Asking the 17-year old female in scenario 1 to monitor her PEFR at home

Ordering high-dose inhaled steroids in scenario 1

Prescribing high pediatric dose of inhaled corticosteroids for a young child with suspected mild asthma ("scenario 3")

Ordering inhaled short-acting beta2-agonist in scenario 3

Selecting xanthines as "first- or second-line" therapies in general

*Canadian Asthma Consensus Conference: Summary of Recommendations (reference 2). Laboratory Centre for Disease Control, Ottawa, Ontario; Price Waterhouse Consultants, Toronto, Ontario

sampling scheme, so that they were representative of the specialty groups on a national basis.

ANOVA was then used to determine whether there were any statistically significant differences in the percentages of the five specialties in making a particular asthma management choice. The Bonferroni test for multiple comparisons was used at a $5 \%$ level of significance $(\mathrm{P}<0.05)$, because many hypotheses were being tested at the same time.

The second type of data analysis was used to determine 
any statistically significant associations, as estimated by odds ratios, between the characteristics of the physician respondents and the asthma management choices that they made in the survey. Using the SAS (Statistical Analysis System (software system) (SAS Institute, Cary, North Carolina), a logistic regression model was used to calculate the odds ratios. Table 1 describes the physician characteristics that comprised the 'independent variables' in the logistic regression model. The left-hand column describes the variables, and the right-hand column describes the possible characteristics. Table 2 shows the asthma management choices that were the ' $\mathrm{d}$ ependent' or 'outcome' variables in the regression model. The left-hand column describes the baseline variables used by both Price Waterhouse Consultants and the LCDC in their respective analyses; the right-hand column shows the additional variables used in the LCDC analysis. A large series of odds ratios were generated by logistic regression models, and their statistical significance was indicated by P.

\section{NEXT STEPS}

Price Waterhouse Consultants submitted their report to LCDC in August 1997, and the main results were discussed at the meeting of the National Asthma Control Task Force in November 1997. Selected findings were presented at the Third National Conference on Asthma and Education ('ASED 3'), held in Vancouver in November 1997. The consultant's report was subsequently released by LCDC in April 1998 for dissemination among the member organizations of the Task Force (unpublished data, Price Waterhouse Consultants: Physician Asthma Management Practices in Canada: Report of a National Survey).

Papers describing the key findings of this national survey are being written by the LCDC and members of the steering committee for submission to major medical journals. Specifically, there will be a 'main paper' highlighting the overall results of the survey, and several 'side papers' describing findings specific to the specialty groups (eg, respirologists, pediatricians and allergists).

\section{CONCLUSIONS}

The findings of the national Physician Asthma Management Survey are expected to help identify the specific topic areas of asthma management that require more physician education and the specific groups of physicians to which the educational interventions should be targeted. The survey findings also serve as the baseline for comparison with any future national survey of physician asthma management practices. Such surveys can help to evaluate the effectiveness of the dissemination and implementation of the updated Canadian Asthma Consensus Guidelines, and the achievement of the objectives of the National Asthma Control Strategy.

ACKNOWLEDGEMENTS: The authors thank the following individuals who contributed significantly to the design and methodology of the study, including the content of the questionnaires and the sampling scheme; the data collection, analysis and interpretation; and the writing or review of manuscripts describing the results of the survey.

Laboratory Centre for Disease Control, Health Canada, Bureau of Cardio-Respiratory Diseases and Diabetes: Dr Felix Li, former Bureau Director; Ms Louise McRae, Program Officer; Dr Charles Mustard, former Chief, Respiratory Disease Division; Dr Frank Mo, Statistical Analyst; Ms Lynne Belle-Isle, former Senior Analyst.

Steering Committee, Physician Asthma Management Study (external members): Dr Robert Beveridge, Canadian Association of Emergency Physicians; Dr Louis-Philippe Boulet, Canadian Thoracic Society; Dr Benjamin Chan, Price Waterhouse Consultants; Dr Lisa Cicutto, Canadian Nurses Respiratory Society; Dr Eric Leith, Canadian Society of Allergy and Clinical Immunology; Dr Ian Mitchell, Canadian Paediatric Society; Dr Grahame Owen, College of Family Physicians of Canada; Dr John Parboosingh, Royal College of Physicians and Surgeons of Canada.

\section{REFERENCES}

1. Ernst P, Fitzgerald JM, Spier S. Canadian Asthma Consensus Conference: Summary of Recommendations. Can Respir J 1996;3:89-100.

2. Grunfeld A, Beveridge RC, Berkowitz J, FitzGerald JM. Management of acute asthma in Canada: an assessment of emergency physician behaviour. J Emerg Med 1997;15:547-56. 


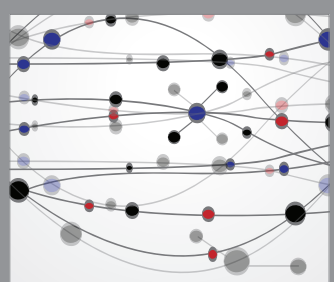

The Scientific World Journal
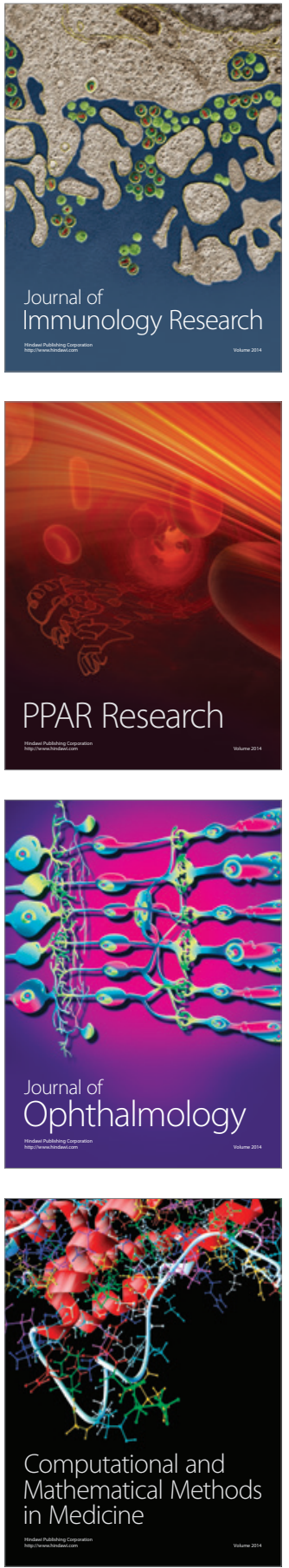

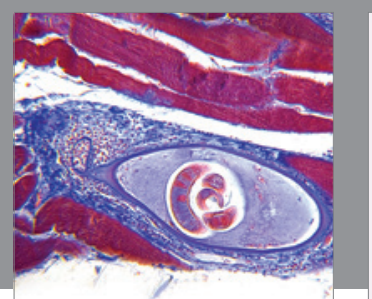

Gastroenterology Research and Practice

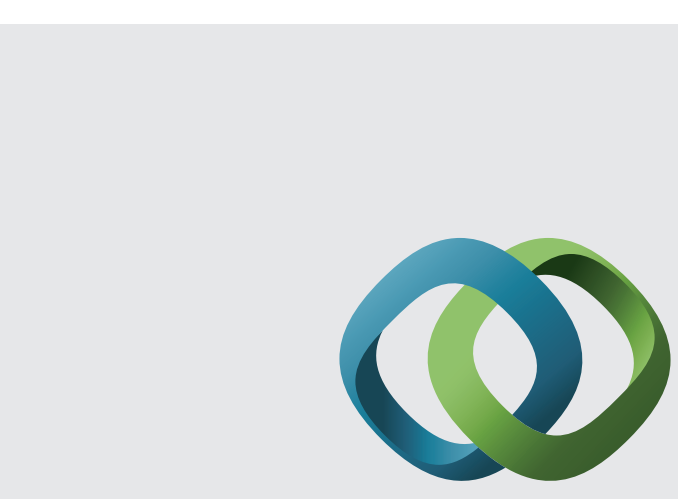

\section{Hindawi}

Submit your manuscripts at

http://www.hindawi.com
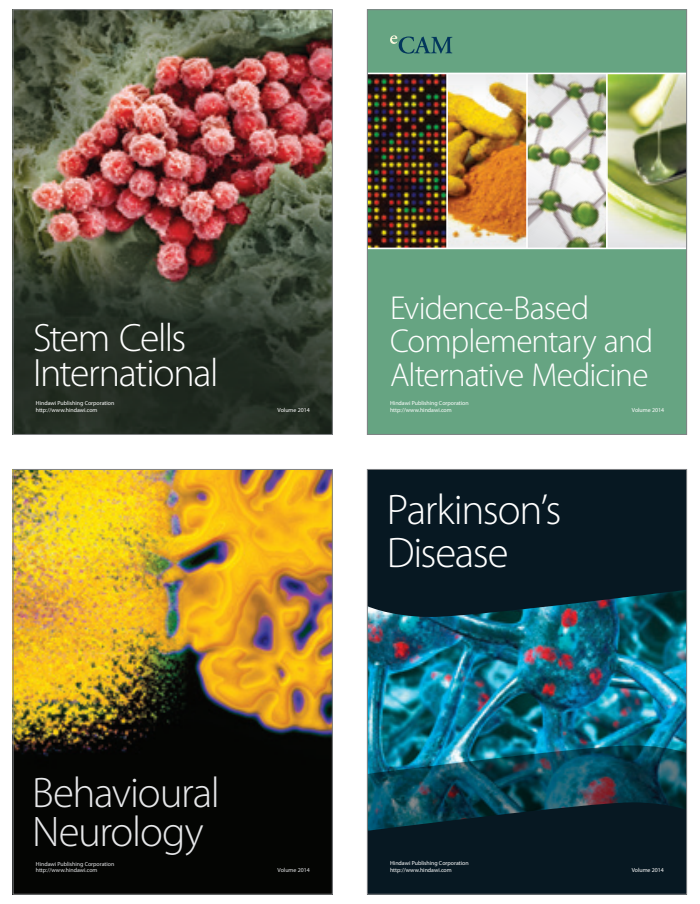
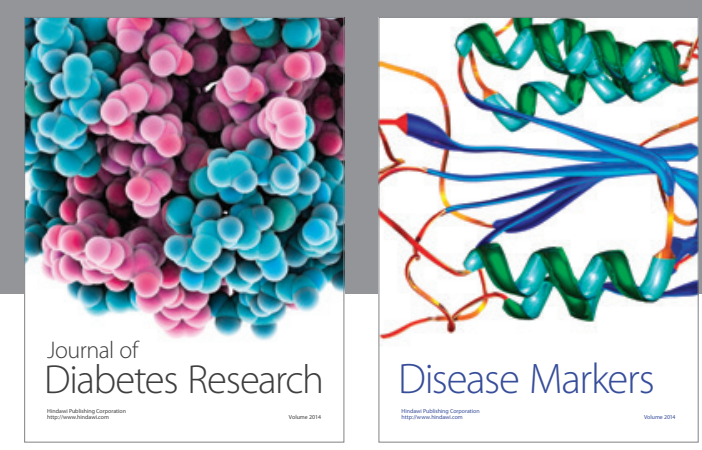

Disease Markers
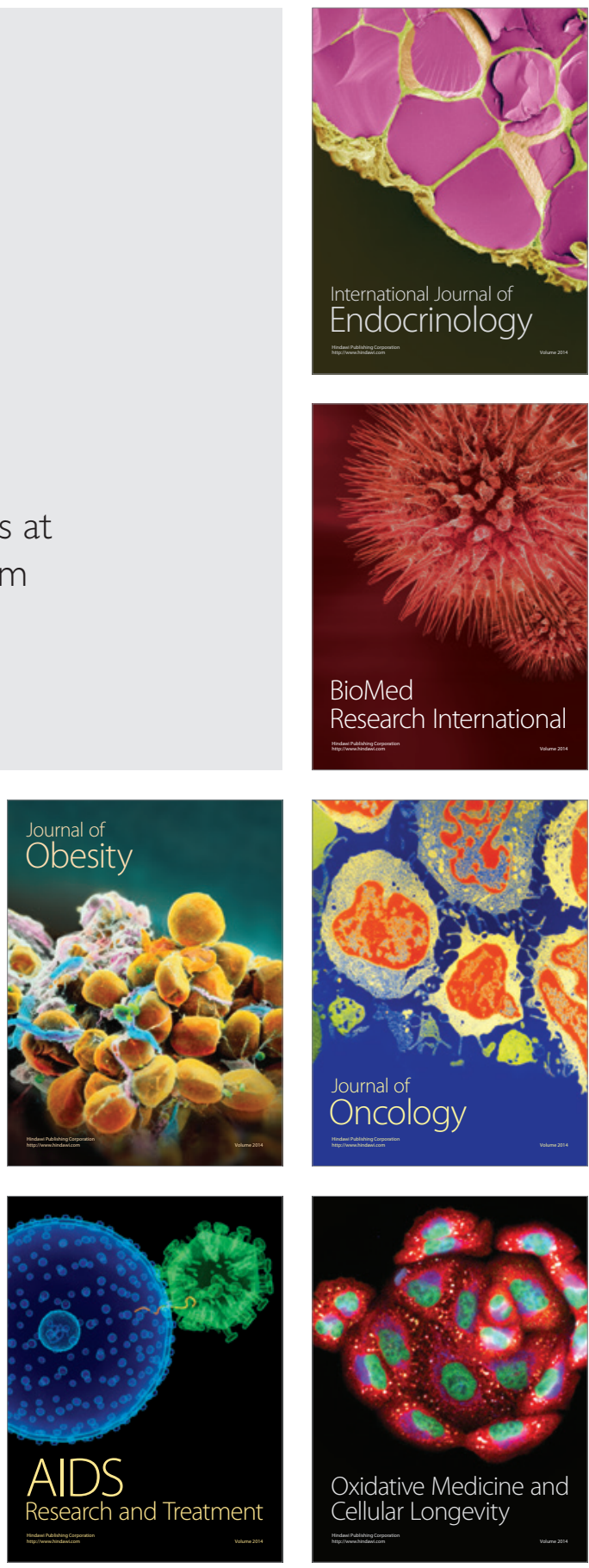